\title{
The Transatlantic Dynamics of European Cultural Diplomacy: Germany, France and the Battle for US Affections in the 1920s
}

\author{
Elisabeth Marie Piller (D) \\ Department of History, University of Freiburg \\ elisabeth.piller@geschichte.uni-freiburg.de
}

\begin{abstract}
The article explores the role of cultural diplomacy in Weimar Germany and France's competing efforts to win the sympathies and support of the United States after the First World War. In the post-war United States, both France and Germany used cultural initiatives to pursue their opposing visions of the new international order: France to maintain and extend wartime cultural alliances beyond the armistice and implement the provisions of the peace treaty; Germany to overturn these very alliances and build a desirable transatlantic 'friendship' in line with its efforts to revise the Versailles Treaty. By focusing on the Franco-German rivalry for US affinities, the article calls attention to the transatlantic dynamics of interwar cultural diplomacy. It shows that the emergence of German cultural diplomacy was strongly shaped by French competition for the affections of politically isolationist Americans and that, in general, the rapid expansion of cultural diplomacy in interwar Europe arose from mutual feelings of crisis, starkly competing ambitions as well as the rapid circulation of ideas and practices.
\end{abstract}

On 20 July 1923, at the very height of the Ruhr crisis, the German ambassador to Washington, Otto Wiedfeldt, sent home an alarming report on French propaganda activities in the United States. At a time when a revision of the Versailles order in general and the end of the French military occupation of the German Ruhr district in particular seemed to hinge on US intervention and a more favorable American public opinion, Wiedfeldt's assessment was gloomy indeed. France, the ambassador lamented, still fed off the wartime sympathy of American elites and continued to hold the favor of university circles and the American Legion, as well as most US churches, newspapers and philanthropic organisations. America's first families, Wiedfeldt reported, 'love or pity "poor little France", go annually to do their shopping in Paris, (their) daughters are brought up in French finishing schools, and - if they served as nurses in the war - now think back to this time with delight'. Yet according to Wiedfeldt this great regard for France was the product not only of long-standing cultural preference and recent military alliance but also of an effective French propaganda campaign. Working through diplomatic missions, as well as the Alliance Française, a host of language schools, the French departments of US universities, theatres, museums and other cultural organisations across the United States, France had systematically cemented its advantageous wartime position in the early 1920s. French Ambassador Jules Jusserand, in Washington for more than twenty years, generously bestowed decorations, awards and honorary doctorates on faithful US Francophiles, always gracing such ceremonies with some words 'for France and against Germany'. In the 'favourable context' of the post-war years, concluded the German ambassador, 'French propaganda has been able to play itself out at will'.

\footnotetext{
1 German Embassy Washington to Auswärtiges Amt (German Foreign Ministry/AA), 20 July 1923, Politisches Archiv des Auswärtigen Amts (PA AA), R 80296.

(C) The Author(s), 2021. Published by Cambridge University Press. This is an Open Access article, distributed under the terms of the Creative Commons Attribution licence (https://creativecommons.org/licenses/by/4.0/), which permits unrestricted re-use, distribution, and reproduction in any medium, provided the original work is properly cited.
} 
The German embassy's exasperated report on French cultural diplomacy was far from an isolated instance. Although the report's particular length (forty-one pages!) and its degree of despair reflected the specific depth of Germany's financial and political crisis in mid-1923, it exemplified two broader and remarkably consistent features of Weimar Germany's politics: an abiding concern for the sympathies of a newly powerful United States, and the constant, well-nigh obsessive observation of French efforts to cultivate US sympathies. This article explores both of these features and their effect on the emergence of a state-driven German cultural diplomacy, in other words systematic efforts to cultivate and manage international cultural relations, after the First World War. Although private actors, including student organisations and US philanthropic foundations, played an important role in interwar cultural relations, this article focuses primarily on the German Foreign Ministry and German diplomats. This emphasis offers a more nuanced and less economics focused perspective on Germany's official Amerikapolitik and also provides broader insights into European politics between the wars. Whereas the development of cultural diplomacy is often treated in a national or bilateral context, the article underlines the importance of transnational circulation and international competition in shaping a then-new set of diplomatic practices. It highlights the transatlantic dimension of European cultural diplomacy during a formative period in the twentieth century.

Scholars have long recognised that German cultural diplomacy in its concerted and state-driven form was a product of the interwar period. ${ }^{2}$ The 1920s established forms of cultural outreach which remain among the standard repertoire and institutional backbone of German cultural diplomacy today. The German Foreign Ministry's Department of Cultural Affairs (Kulturabteilung, est. 1920), the forerunner of the Goethe-Institut (est. 1923), the German Academic Exchange Service (Deutscher Akademischer Austauschdienst, est. 1925), the Alexander von Humboldt Foundation (Alexander von Humboldt-Stiftung, est. 1925) and the Deutsche Welle (est. 1929) all hail from that period. Aware of post-war Germany's limited hard power options, Weimar statesmen like Foreign Minister Gustav Stresemann (1923-9) turned the management of cultural relations into a legitimate field of German foreign policy. In particular, they used it as an instrument of German revisionism - efforts to revise the economic, territorial, military and moral implications of the Versailles Peace Treaty. Depending on the target region, German officials supported ethnic newspapers, German language teaching, academic exchanges and art exhibitions in order to facilitate Germany's commercial expansion (Latin America, South Eastern Europe), to maintain its territorial claims in formerly German lands (Eastern Europe) or to overcome its isolation and thereby restore its ability to argue its grievances from within the family of nations (the Western Allies). ${ }^{3}$

The historiography on German cultural diplomacy is characterised by absences and imbalances. For one, we continue to underestimate the sophistication and nuance of Weimar public diplomacy, particularly with regard to the United States. Historians have focused almost exclusively on Weimar's economic and financial - not cultural - diplomacy. While we know that Stresemann and other German officials successfully used economic diplomacy to improve relations with a newly important United States, we know little about how they used Germany's rich cultural heritage to the same end. ${ }^{4}$ As a

\footnotetext{
2 Manfred Abelein, Die Kulturpolitik des Deutschen Reiches und der Bundesrepublik Deutschland. Ihre verfassungsgeschichtliche Entwicklung und ihre verfassungsrechtlichen Probleme (Köln: Westdeutscher Verlag, 1968); Kurt Düwell, Deutschlands auswärtige Kulturpolitik, 1918-1932 (Köln: Böhlau, 1976); more recently, Eckard Michels, Von der Deutschen Akademie zum Goethe-Institut. Sprach- und auswärtige Kulturpolitik 1923-1960 (München: Oldenbourg, 2005); Frank Trommler, Kulturmacht ohne Kompass. Deutsche auswärtige Kulturbeziehungen im 20. Jahrhundert (Köln: Böhlau, 2013); Benjamin Martin, The Nazi-Fascist New Order for European Culture (Cambridge, MA: Harvard UP, 2016).

3 Stephen G. Gross, Export Empire: German Soft Power in South Eastern Europe, 1890-1945 (New York: Cambridge UP, 2015); Stefan Rinke, Der letzte freie Kontinent. Deutsche Lateinamerikapolitik im Zeichen transnationaler Beziehungen, 1918-1933 (Stuttgart: Hans-Dieter Heinz, 1996); Norbert Krekeler, Revisionsanspruch und geheime Ostpolitik der Weimarer Republik. Die Subventionierung der deutschen Minderheit in Polen 1919-33 (Stuttgart: Deutsche Verlags-Anstalt, 1973); Tara Windsor, 'Rekindling Contact: Anglo-German Academic Exchange after the First World War', in Heather Ellis and Ulrike Kirchberger, eds., Anglo-German Scholarly Relations in the Long Nineteenth Century (Leiden: Brill, 2014), 212-31.

4 Manfred Berg, 'Germany and the United States: The Concept of World Economic Interdependence', in Carole Fink, Axel Frohn et al., eds., Genoa, Rapallo, and European Reconstruction in 1922 (New York: Cambridge UP, 1991), 77-93; two
} 
consequence, we not only fail to appreciate the breadth of German policies towards a politically isolationist United States, but also run the danger of mistaking abrasive and political forms of German propaganda (such as the well-researched and deeply racist 'black horror' campaign) as representative of Weimar public diplomacy. Ignoring the cultural dimension of Germany's Amerikapolitik thus feeds into old stereotypes which cast the Weimar Republic as unable to rise above revisionist propaganda and develop a constructive way to market itself at home and abroad. ${ }^{5}$

Moreover, the development of German cultural diplomacy is too often understood in a national, rather than a European or global, context. Accordingly, the rapid expansion of cultural diplomacy as a new policy field in the 1920s is usually attributed to the continuance of wartime propaganda traditions as well as Germany's ambition to use its remaining cultural capital to offset its loss of hard power. ${ }^{6}$ But the experiences of the 1920s, especially Weimar Germany's salient conflict with France, also shaped the development of cultural diplomacy in profound ways. While certain aspects of Germany's cultural representation (such as its participation in world's fairs) have long been understood as an element of great power rivalry, and while most studies do mention the importance of French efforts, the overall influence of French competition on the intensity, methods and ultimately objectives of German cultural diplomacy has not been systematically evaluated. ${ }^{7}$ Frank Trommler's recent call to understand the history of German cultural diplomacy as a reciprocal and dialectic process across borders has so far not been heeded, at least not with regard to the interwar years. ${ }^{8}$ This is especially unsatisfying because historians of Franco-US relations have long established the significance of France's intense efforts to retain American sympathies vis-à-vis Germany after the Great War. ${ }^{9}$ Robert Young has even spoken of a 'Franco-German battle for American affections'. Yet the German side of this 'battle', and hence its reciprocal dynamics, remain obscure.

Based on research in German and US archives and focusing on state actors, this article makes three major points: first, it underlines France and Germany's substantial use of cultural diplomacy in interwar politics. The decision to allocate comparatively large financial and organisational resources to a hitherto small policy field reflected both countries' economic and political crises, which could be solved only with

exceptions, Michael Wala, “Gegen eine Vereinzelung Deutschlands": Deutsche Kulturpolitik und akademischer Austausch mit den Vereinigten Staaten von Amerika in der Zwischenkriegszeit', in Manfred Berg and Philipp Gassert, eds., Deutschland und die USA in der Internationalen Geschichte des 20. Jahrhunderts (Stuttgart: Steiner, 2004), 30315; Rennie Brantz, 'German-American Friendship: The Carl Schurz Vereinigung, 1926-1942', International History Review, 11, 2 (1989), 229-51.

5 See Julia Roos, 'Nationalism, Racism and Propaganda in Early Weimar Germany: Contradictions in the Campaign against the "Black Horror on the Rhine"', German History, 30, 1 (2012), 45-75; Corey Ross, 'Mass Politics and the Techniques of Leadership: The Promise and Perils of Propaganda in Weimar Germany', German History, 24, 2 (2006), 184-211.

6 Friedrich Dahlhaus, Möglichkeiten und Grenzen auswärtiger Kultur- und Pressepolitik. Dargestellt am Beispiel der deutsch-türkischen Beziehungen 1914-1928 (Frankfurt am Main: Peter Lang, 1990), 243.

7 On the world's fairs, see Wolfram Kaiser, 'The Great Derby Race: Strategies of Cultural Representation at Nineteenth-Century World Exhibitions', in Jessica Gienow-Hecht and Frank Schuhmacher, eds., Culture and International History (New York: Berghahn, 2003), 45-59. Little has been written on the role of competition in interwar cultural diplomacy, see Zsolt Nagy, 'National Identities for Export: East European Cultural Diplomacy in Inter-War Pittsburgh', Contemporary European History, 20, 4 (2011), 435-53; Jennifer Dueck, 'International Rivalry and Culture in Syria and Lebanon under the French Mandate', in Jessica Gienow-Hecht and Mark Donfried, eds., Searching for a Cultural Diplomacy (New York: Berghahn Books, 2010), 137-61; on the learning processes involved in FrancoGerman competition in general, see Martin Aust and Daniel Schönpflug, eds., Vom Gegner lernen: Feindschaften und Kulturtransfers im Europa des 19. und 20. Jahrhunderts (Frankfurt: Campus, 2007).

8 See Trommler, Kulturmacht, 32-4.

9 William Keylor, 'How They Advertised France: The French Propaganda Campaign in the United States during the Break Up of the Franco-American Entente, 1918-1923', Diplomatic History, 17, 3 (July 1993), 351-73; Dorothee Bouquet, 'French Academic Propaganda in the United States, 1930-39', in Richard Garlitz and Lisa Jarvinen, eds., Teaching America to the World and the World to America (London: Palgrave Macmillan, 2012), 155-72; Whitney Walton, 'Internationalism and the Junior Year Abroad: American Students in France in the 1920s and 1930s', Diplomatic History, 29, 2 (2005), 255-78; Alain Dubosclard, 'Diplomatie culturelle et propagande française aux États-Unis pendant le premier vingtième siècle', Revue d'Histoire Moderne et Contemporaine, 48 (2001), 102-19; Robert J. Young, Marketing Marianne: French Propaganda in America, 1900-1940 (New Brunswick, NJ: Rutgers UP, 2004). 
US help. Their pursuit of very different and often incompatible visions of post-war Europe forced French and German officials to expand their traditional diplomatic toolkit and to subject cultural relations to foreign policy concerns. Second, the article uses the Franco-German case to explore the mechanisms of mutual observation and emulation, calling attention to the international and transnational dynamics of cultural diplomacy. Educators and diplomats in each country closely monitored the other's efforts and, commonly overestimating their rival's successes, adopted similar practices. As will be shown, the expansion of European cultural diplomacy in the interwar years was the result of shared feelings of crisis, starkly competing ambitions and the rapid circulation of ideas and practices. Finally, the article reminds us that European interwar politics must be understood in a wider international context. The relative decline of Europe and the rise of new powers like the United States informed European approaches. In the end, the United States's key financial involvement in, and its political withdrawal from, interwar Europe helped re-direct European attention to the seemingly 'non-political' field of culture.

After a brief retrospect on the origins of German cultural diplomacy, the article explores these issues in three parts. It first highlights the years 1919-24 as an influential and often overlooked moment in the emergence of German cultural diplomacy, during which French competition proved of paramount importance. It then looks at the development of transatlantic student exchanges from the mid-1920s as an instructive case study and highlights the pivotal role the United States played in shaping reciprocal forms of cultural outreach. The article concludes by using the Franco-German case study to arrive at broader insights into the dynamics which shaped the evolution of state-driven cultural diplomacy in interwar Europe.

\section{The Origins of German Cultural Diplomacy}

As a foreign policy field German cultural diplomacy developed truly only in the 1920s. Yet its roots go back to at least the late nineteenth century. Early efforts owed much to the cultural zeal and imperialist vision of Germany's educated bourgeois classes (Bildungsbürgertum). Accelerating around the turn of the century, German teachers, professors, physicians and lawyers (tacitly supported by ministerial officials) founded a host of 'international organisations' (Auslandsvereine) to promote German culture and language abroad. Cultural promotion, they hoped, would help Wilhelminian Germany secure its 'rightful place' in the world and bolster its commercial and political influence vis-à-vis imperial rivals like France and the United Kingdom. ${ }^{10}$ While such ambitions focused largely on China, Latin America and the crumbling Ottoman Empire, private and official groups were also active in the United States, where they hoped to use existing cultural ties to salvage the declining transatlantic relationship. The establishment of one of the world's first professorial exchanges between Harvard University and the University of Berlin (1905) and the dispatching of German professors to reach out to German-Americans (after 1906) illustrate Berlin's, especially Emperor Wilhelm II and the Prussian Ministry of Culture's, budding interest in cultivating cultural relations with the new great power across the Atlantic. ${ }^{11}$ For the first time, the German state tried to capitalise on the myriad transatlantic connections which had been forged in the previous century through emigration, the thousands of American students educated at German universities and the high regard which German music enjoyed among US elites. ${ }^{12}$ Still, these efforts remained relatively haphazard and often disconnected from larger foreign policy agendas. The German Foreign Ministry in particular did not develop a

10 Jürgen Kloosterhuis, Friedliche Imperialisten. Deutsche Auslandsvereine und auswärtige Kulturpolitik, 1906-1918 (Frankfurt: Lang, 1994); Rüdiger vom Bruch, Weltpolitik als Kulturmission. Auswärtige Kulturpolitik und Bildungsbürgertum in Deutschland am Vorabend des Ersten Weltkrieges (Paderborn: Schöningh, 1982); Stefan Manz, Constructing a German Diaspora: The 'Greater German Empire', 1871-1914 (London: Routledge, 2014).

11 Ragnhild Fiebig-von Hase, 'Die politische Funktionalisierung der Kultur: der deutsch-amerikanische Professorenaustausch 1904-1914', in Ragnhild Fiebig-von Hase and Jürgen Heideking, eds., Zwei Wege in die Moderne: Aspekte der deutschamerikanischen Beziehungen 1900-1918 (Trier: Wissenschaftlicher Verlag, 1997), 45-88.

12 See Anja Werner, The Transatlantic World of Higher Education (New York: Berghahn, 2013); Jessica Gienow-Hecht, Sound Diplomacy: Music and Emotions in Transatlantic Relations, 1850-1920 (Chicago: Chicago University Press, 2009); Frederick Luebke, Germans in the New World (Champaign, IL: University of Illinois Press, 1990). 
clear conception of, let alone a substantial commitment to, this nascent policy field, at least not in the United States. $^{13}$

The Great War and its aftermath profoundly changed this situation. From the first, all belligerents understood the war as a cultural conflict that had to be fought, too, for the emotional and moral allegiance of the neutral world, especially the United States. ${ }^{14}$ Within months of August 1914 the main European powers had established propaganda offices (the Zentralstelle für Auslandsdienst in Berlin, the Bureau de Presse in Paris and Wellington House in London), which focused not only on press or picture propaganda but also drew on artists, writers and academics to mobilise sympathies across the Atlantic. ${ }^{15}$ If wartime exigencies had already prompted Germany to expand its commitment to public diplomacy, its abject failure to sway US opinion strongly reinforced this trend. Indeed, German attempts to preach the superior value of German culture and activate ethnic ties in the United States proved not only ineffective but counterproductive. They alienated even sympathetic Americans, marked German-Americans as a potential enemy within, and - in light of wartime German atrocities - helped turn an once admired German culture into a disdained 'Kultur'. ${ }^{16}$ With the US entry in the war in April 1917, German politicians like future Foreign Minister Gustav Stresemann began to dissect German public relations failures and to call for systematic and state-funded efforts to restore Germany's 'distorted image' in the world. ${ }^{17}$ The founding of a 'cultural desk' at the German Foreign Ministry just a few months later attests to this budding commitment to cultural diplomacy.

Pre-war traditions and wartime developments aside, German cultural diplomacy was only truly institutionalised after 1918. This process cannot be understood outside of the context of Germany's post-war crisis. While German victory might well have stifled calls for a concerted public diplomacy as it did in the United Kingdom - German defeat had precisely the opposite effect. ${ }^{18}$ Internationally isolated and bereft of its former territorial, commercial and military strength, Germany's cultural standing now appeared one of the few remaining reservoirs of international prestige and one of the few available means to reclaim its great power status. After November 1918 ministerial officials, politicians, academics and journalists came to hope that a more careful and concerted use of Germany's 'soft power' might help offset its loss of 'hard power. ${ }^{19}$ Not surprisingly, then, the establishment of a Department of Cultural Affairs (Kulturabteilung) was one of the true novelties of the 1919/20 reforms of the German Foreign Ministry. ${ }^{20}$ Its task was to systematically cultivate Germany's remaining intangible assets, including the sympathies of the German diaspora and the prestige bound up in the country's technological, musical and scientific achievements.

And yet, while the founding of the Department of Cultural Affairs was an unprecedented step towards a new field of international politics, it was hardly, at least at this point, a genuine re-orientation of German foreign policy. For one, as German policy makers pondered how to re-establish a German presence in the world, cultural diplomacy was neither their only, nor their preferred option. Enthusiasm for a cultural approach trailed notably behind enthusiasm for a 'forceful' political propaganda to serve Germany's primary foreign policy interest: the revision of the

\footnotetext{
13 German Consulate Chicago to German Embassy Washington, 23 Sept. 1908, PA AA, Kaiserlich Deutsche Botschaft in Washington, No. 461.

14 Chad Fulwider, German Propaganda and US Neutrality in World War I (Columbia: University of Missouri Press, 2016).

15 Jürgen Wilke, 'German Foreign Propaganda in the United States during World War I: The Central Office for Foreign Services', in Jürgen Wilke, ed., Propaganda in the 20th Century: Contributions to its History (Cresskill N. J.: Hampton Press 1998), 7-23.

16 Frank Trommler, 'The Lusitania Effect: America's Mobilization against Germany in World War I', German Studies Review, 32, 2 (May 2009), 241-66.

17 Gustav Stresemann in Verhandlungen des Deutschen Reichstags, 29 Mar. 1917, 2850 D-2851 A.

18 Philipp Taylor, The Projection of Britain, British Overseas Publicity and Propaganda 1919-1939 (Cambridge: Cambridge UP, 1981), 79.

19 See Ernst Pöppinghaus, Moralische Eroberungen. Kultur und Politik in den deutsch-spanischen Beziehungen der Jahre 1919-1933 (Frankfurt: Vervuert, 1998), 104ff.

20 Düwell, Deutschlands auswärtige Kulturpolitik, 78.
} 
Versailles order. ${ }^{21}$ Moreover, the creation of the Department of Cultural Affairs in 1919/20 did not equal a fully articulated cultural policy. In reality, it would take years to develop a German cultural diplomacy with clearly defined fields, methods and partners. That it eventually did develop and came to play a prominent role in transatlantic relations, it will be argued, owed much to the Franco-German competition for US sympathies.

\section{German Cultural Diplomacy, French Competition and the United States, 1919-24}

After the First World War the United States became of paramount importance to Germany's revisionist foreign policy. A fairly minor actor in Europe before the war, the United States's financial strength and its role as Allied creditor gave it a unique position in post-war European politics, especially in one of its most central and contentious issues: the reparations question. Left unsettled by the peace treaty, the total amount and annuities of German reparations payments to the victors was never a merely financial question. Rather the issue stood at the very centre of Europe's crisis-ridden efforts to establish a stable post-war order and, as such, at the heart of competing French and German ambitions. A large reparations total and high annuities would significantly weaken the German economy, thus furthering not only France's economic recovery (and the repayment of its $\$ 3$ billion debt to the United States) but also its sense of security vis-à-vis its revanchist neighbour. By contrast, a small reparations total or low annuities would facilitate Germany's economic resurgence and, by extension, its return to a halfhegemonic position in Europe. ${ }^{22}$ Since any reparations deal required the involvement of the United States, France and Germany both looked for US support in their respective efforts to enforce/dismantle the Versailles order. In Paris, as in Berlin, how to retain/win the sympathies of an increasingly isolationist American public became a question of great significance.

In Berlin at least, just how to go about this was far from clear. Despite the widely acknowledged importance of the United States, Weimar Germany had no strategy of how to win over the US public, let alone one that gave precedence to cultural diplomacy. Larger policy considerations were partly to blame. Indeed, German policy makers were initially confident that US economic interest in a stable Europe would by itself effect a timely US mediation in the reparations question. Only when US involvement remained elusive - in particular after the US Senate's refusal to ratify the Versailles peace treaty in early 1920 - did German leaders identify the United States's hostile public opinion as a primary foreign policy concern. ${ }^{23}$ Even then, however, they failed to see what Germany could actually do to improve US sentiment. One of the main problems was that Americans, having been the primary targets of international and domestic propaganda during the war, were sensitive 'almost to the point of obsession' (as one British observer remarked in 1919) about any, especially any German, attempts to influence them. ${ }^{24}$ Moreover, the war had eroded the transatlantic ties grown through a century of ethnic and academic migration. Germany's language, science and culture had been stigmatised, its existing cultural organisations closed and its traditional advocates, German-Americans, stripped of their voice and ethnic identity. ${ }^{25}$ The war, ambassador Wiedfeldt lamented in 1923, has 'cut all ties' and left Germany with 'nothing. ${ }^{26}$ Under these circumstances, Berlin at first settled on revisionist propaganda (such as agitation against the 'black horror'), which it conducted through ostensibly private front organisations. ${ }^{27}$ By contrast, cultural initiatives were discussed, if at all, in barely enthusiastic terms as a potential 'substitute' for the 'almost hopeless

\footnotetext{
${ }_{21}$ Ulrich Heinemann, Die verdrängte Niederlage. Politische Öffentlichkeit und Kriegsschuldfrage in der Weimarer Republik (Göttingen: Vandenhoeck \& Ruprecht, 1983).

22 Stephen Schuker, The End of French Predominance in Europe: The Financial Crisis of 1924 and the Adoption of the Dawes Plan (Chapel Hill, NC: University of North Carolina Press, 1976).

23 See, for example, German Embassy Washington to AA, 18 Oct. 1922, PA AA, R 80134.

24 Quoted from Taylor, The Projection of Britain, 68.

25 Aufzeichnung (consul Dr. Kraske), 10 Oct. 1924, PA AA, R 60105.

26 German Embassy Washington to AA, 20 July 1923, PA AA, R 80296.

27 Keith Nelson, 'Black Horror on the Rhine: Race as a Factor in Post-World War I Diplomacy', Journal of Modern History, 42, 4 (1970), 606-27.
} 
endeavour of open propaganda'. ${ }^{28}$ Faced with US suspicions and affected by a lack of expertise, partners and opportunity, German cultural diplomats struggled to find their way to constructive activity after the war.

That they eventually did owed much to their close observation of what the French were doing to retain US sympathies. Indeed, the early 1920s saw a veritable flood of German memoranda, missives, pamphlets and newspaper articles on the real and imagined advances of the French rival. ${ }^{29}$ To be sure, France had long been recognised and admired as a pioneer of cultural diplomacy. Even before the war, large private organisations like the Alliance Française (est. 1883) had sought to expand the great prestige and influence which French art, language, fashion, lifestyle and vacations enjoyed with American elites. ${ }^{30}$ German observers always marveled at the zeal and the unity of purpose that seemed to animate French cultural missionaries. ${ }^{31}$ But France was also among the first countries to officially subsidise and coordinate such activities. In 1910 the National Office for French Universities and Schools (Office National des Universités et Écoles Françaises; ONUEF) was opened to more systematically cultivate academic relations in the national interest. This infrastructure was expanded and professionalised after 1914. In January 1920 a cultural diplomacy hub at the Quai d'Orsay, the French Works Abroad Service (Service des Euvres Françaises à l'Étranger; SOFE), was founded to support not only academic relations, but also sports events, tourism and art exhibitions. ${ }^{32}$ Alongside new international offices at French universities, national tourist organisations and bilateral friendship societies, the SOFE sought to use France's connections and cultural radiance to maintain, in the cultural field, the gains of a hard-won victory.

Not surprisingly, these French developments received significant German attention. The annual French parliamentary debates on the cultural budget were closely followed in Berlin, as were France's efforts to capitalise on its long-standing cultural ties and its wartime alliance with Americans. ${ }^{33}$ German diplomats took meticulous note of the frequent visits of French war heroes to the United States, the large number of Franco-American war commemorations as well as the courteous treatment of American visitors to France and their 'invariable' tour of the battlefields and devastated regions. ${ }^{34}$ At the same time, German observers recognised that francophile US organisations like the American Legion or the Carnegie Endowment for International Peace were hardly less invested in Franco-American amity than Paris. In fact, much of France's cultural clout and the public sympathy it enjoyed seemed to rest with elite American women, who, German diplomats believed, were by their nature more susceptible to the 'shallow elegance' of French culture (which was itself

28 Schmidt-Ott to AA, 4 May 1921, PA AA, R 64997.

29 German Legation Stockholm to AA, 9 Nov. 1920, PA AA, R 60430; German Embassy Paris to AA, 17 Dec. 1921, PA AA, R 60430; Bernhard Harms, Französische Kulturpropaganda in den Vereinigten Staaten von Amerika (Kiel: Institut für Weltwirtschaft und Seeverkehr, 1924); Anon., 'Wissenschaft und Schule im Dienste der französischen Propaganda', Deutsche Arbeit, 23, 11 (Aug. 1924), 283-8; 'Frankreichs Propaganda Etat', Berliner Börsen-Courier, 12 Jan. 1924, (Clipping), PA AA, R 60431; 'Französische Propaganda', Deutsche Allgemeine Zeitung, no 278/79, 17 June 1925 (Clipping), PA AA R 65147; Karl Remme and Margarethe Esch, Die französische Kulturpropaganda (Berlin: Preußische Druckerei- und Verlagsaktiengesellschaft, 1927); AA to German Embassy Paris, 5 July 1929, PA AA, R 61187; Hans Göttling 'Die Tätigkeit der Alliance Française und Mission Laïque in den Jahren 1927, 1928, 1929, 1930', PA AA, R 61187.

30 See Harvey Levenstein, Seductive Journey: American Tourists in France from Jefferson to the Jazz Age (Chicago, IL: University of Chicago Press 1998); on US students in France and Germany and the early years of the Franco-German competition see Whitney Walton, Internationalism, National Identities, and Study Abroad (Stanford: Stanford University Press, 2010), 12-38.

31 Paul Rühlmann, 'Französische und Deutsche Kulturpropaganda. Vergleich und Kritik', Neue Jahrbücher für Wissenschaft und Jugendbildung, 6, 1 (1930), PA AA, R 61125.

32 For an early but concise presentation of French cultural diplomacy from the nineteenth century onward, see Ruth Emily McMurry and Muna Lee, The Cultural Approach: Another Way in International Relations (Chapel Hill: University of North Carolina Press, 1947), 9-34; see also the studies cited in fn 9.

33 See, for example, Aufzeichnung VI W 2640 (on French budget 1930), ca. Dec. 1929, PA AA, R 61187.

34 German Embassy Washington to AA, 27 Dec. 1922, PA AA, R 80295; German Embassy Washington to AA, 7 June 1924 , PA AA, R 60447; German Embassy Paris to AA, 19 Aug. 1924, PA AA, R 60447. 
often gendered feminine). ${ }^{35}$ The German consul general in New York tellingly referred to a charity fashion show put on by the American Committee for Devastated France as yet another piece of French propaganda. ${ }^{36}$ Even as disagreements over disarmament and war debt began to strain Franco-US relations in the early 1920s, and even as Paris itself bemoaned its declining influence in the United States, German observers never doubted the allure of French culture, the continued emotional power of wartime alliances or the skill and devotion of those Americans and Frenchmen who sought to maintain them. ${ }^{37}$ Nor did they doubt the essentially anti-German character of these efforts. German diplomatic correspondence habitually portrayed heiress Anne Morgan, President of the American Committee for Devastated France, as a raging Germanophobe, while Ambassador Wiedfeldt characterised Georges Clemenceau's informal 1922 tour of the United States as 'a diplomatic assault on Germany. ${ }^{38}$

German trepidations about pro-French efforts (including seemingly trivial ones like fashion shows) point to a number of German assumptions about US society. First and foremost, they speak to the belief that US public opinion was particularly influential in shaping US foreign policy and that, given its aversion to European politics and the allegedly disproportionate public influence of women, it was best reached by emotional and cultural appeals. ${ }^{39}$ But German concerns also attest to the paranoid state of mind in the early 1920s. While competition had long shaped FrancoGerman relations, post-war antagonisms led Germans to overstate both the menace and malice of the French 'enemy', a term which was used in diplomatic correspondence until the mid-1920s. In light of the two countries' competing ambitions, transatlantic relations were often seen as a zero-sum game, where every French gain in US sympathies invariably translated into a German loss. Accordingly, even routine French courtesies could easily be blown out of proportion and could appear part of a sinister, quasi-Machiavellian plot. As Paul Rühlmann, a member of the Foreign Ministry's wartime propaganda office, noted in representative hyperbole in 1919, in the end French cultural propaganda is not pure, real cultural propaganda, but power politics under the cloak of cultural policy, often so skilfully draped that its true purpose - world domination - is hardly discernible'. ${ }^{40}$

The obsessive attention to French efforts shaped Weimar cultural diplomacy from the very first. The creation of the Foreign Ministry's Department of Cultural Affairs in 1920, the German Tourism Promotion Bureau (Reichszentrale für deutsche Verkehrswerbung, est. 1920), the Union of German Universities (Verband der deutschen Hochschulen, est. 1920) and the Germany Academy (Deutsche Akademie, the forerunner of the Goethe Institut, est. 1923) were all premised on French competition. ${ }^{41}$ This is not to suggest that these organisations conducted a concerted, let alone successful cultural diplomacy. From the beginning, initiatives to capitalise on the remnants of Germany's cultural prestige in the United States through musical performances, academic guest lectures and American tourism foundered on a lack of funds, experience and public goodwill. ${ }^{42}$ While France built on the momentum of the Great War's emotional and moral alliances, Germany felt constantly

35 Paul Rühlmann, for example, commented on the international 'magnetism' of French culture which combined 'a typical French gaiety and affability with womanlike pliability (frauenhafter Schmiegsamkeit)', see Rühlmann, 'Französische und Deutsche Kulturpropaganda'.

36 German Consulate General New York to AA, 12 Apr. 1923, PA AA, R 80295.

37 German Embassy Washington to AA, 30 Jan. 1925, PA AA, R 64887; German Consulate General San Francisco to AA, 6 Dec. 1927, PA AA, R 61130; on Franco-American differences, Keylor, 'How They Advertised France', 371.

38 German Embassy Washington to AA, 27 Dec. 1922, PA AA, R 80295; German Embassy Washington to AA, 7 June 1924, PA AA, R 60447.

39 German Embassy Washington to AA, 15 Sept. 1924, PA AA, R 80297.

40 Paul Rühlmann, Kulturpropaganda. Grundsätzliche Darlegungen und Auslandsbeobachtungen (Charlottenburg: Deutsche Verlagsgesellschaft für Politik und Geschichte, 1919), 15.

41 See, for example, Düwell, Deutschlands auswärtige Kulturpolitik, 42; Michels, Von der Deutschen Akademie, 12; on German tourism and the Franco-American context see Elisabeth Piller, 'Managing Imponderables: The Rise of U.S. Tourism and the Transformation of German Diplomacy, 1890-1933', Diplomatic History, 44, 1 (2020), 47-75.

42 These obstacles are covered in more detail in Elisabeth Piller, Selling Weimar: German Public Diplomacy and the United States, 1918-1933 (Stuttgart: Steiner, 2021), Chapter 3; for the irreconcilable attitude of many German academics see 
dragged down by the deadweight of recent enmity. ${ }^{43}$ And yet German observations of France in the early 1920s set important precedents which would shape German cultural diplomacy for decades to come. Apart from the establishment of the above-mentioned organisations this was true in two ways. For one, the fact that France was so serious about cultural diplomacy increased its acceptance among the traditionally conservative and initially sceptical German Foreign Service. As French efforts forced German diplomats to worry about mundane matters like guest lecturers at Harvard, American tourists in Paris or fashion shows in New York, cultural relations acquired a foreign policy significance they had not previously held. ${ }^{44}$ Moreover, it was in response to French successes and blunders that Berlin slowly moved away from wartime propaganda traditions and towards a cultural course of action in the United States.

Although the embrace of cultural diplomacy was a gradual process, Germany's 'year of crises' in 1923 proved a catalyst for this development. The French occupation of the Ruhr in January 1923 in response to German reparations defaults escalated the reparations struggle, reinforced Berlin's hope for a US intervention, intensified German paranoia about French propaganda - and brought the young republic close to economic and political ruin. Yet, paradoxically, this time of intense strain forged a stronger commitment to a seemingly elusive subject like cultural diplomacy, and did so by building on the French example in two different but complementary ways. ${ }^{45}$ For one, a notable French blunder in the spring of 1923 once more illustrated the limits of political propaganda. Faced with mounting US criticism over the Ruhr occupation, the French consulate in New York had strayed from Ambassador Jusserand's cautious course and established a French Bureau of Information to more aggressively advertise French positions. The result, however, was an almost instantaneous backlash in the US press. ${ }^{46}$ Commenting on this rare French misstep, German Ambassador Wiedfeldt found US opposition to foreign influences steadily rising and noted that if such was the rejection to befall a recent ally, any German propaganda was entirely out of the question. ${ }^{47}$ As he concluded in his long report a few months later, 'propaganda is only disadvantageous in this country. ${ }^{48}$

At the same time, France continued to demonstrate the value of a cultural approach not as a mere 'substitute' for propaganda but as a valuable strategy in and of itself. As the German ambassador informed Berlin, clearly with French efforts in mind, 'since we cannot hope to reach 110 million people through grand propaganda like talks, films or newspapers . . without running the danger of being charged with 'German Propaganda' and thereby suffocating the hopeful seedlings of a more favourable climate of opinion, we are mostly left with entering into personal relations with influential people and explaining to them how things are. ${ }^{49}$ Importantly, by mid-1923 this assessment was also shared by the German Foreign Ministry's influential American Department. As one of its memoranda noted, American 'war psychosis' remained strong and could not be overcome 'by "propaganda" alone'. Rather it would take careful cultivation of personal and cultural ties to slowly erase US francophilia and provide public resonance for Germany's revisionist ambitions. ${ }^{50}$ Ironically, it was at the very

Eduard Meyer, Die Vereinigten Staaten von Amerika. Geschichte, Kultur, Verfassung und Politik (Frankfurt a. M.: Heinrich Keller, 1920), 180-1.

43 German Embassy Washington to AA, 15 Oct. 1923, PA AA, R 80296.

44 The files on 'political and cultural propaganda' created by the German Foreign Ministry's American Department (Amerikaabteilung) after 1921 (PA AA, R 80293 - R 80320) detail the close attention to French initiatives.

45 German Embassy Washington to AA, 7 Jan. 1923, in Akten zur deutschen Auswärtigen Politik (ADAP) Series A, Vol 7 (Göttingen: Vandenhoeck \& Ruprecht, 1989), 38-41; Reichskanzlei, Circular, 'Aufzeichnung des Pressechefs der Reichsregierung über die Aufklärungsarbeit im In- und Ausland', 18 Apr. 1923 in ibid., 469-76.

46 Young, Marketing Marianne, 84-6.

47 German Embassy Washington to AA, 29 Apr. 1923, PA AA, R 80295.

48 German Embassy Washington to AA, 15 Mar. 1923, PA AA, R 121326; German Embassy Washington to AA, 20 June 1926, PA AA, R 65147.

49 German Embassy Washington to AA, 25 Mar. 1923, PA AA, R 80135.

50 III A 1345, Aufzeichnung, ca. May/June 1923, PA AA, R 80135. 
height of Germany's post-war crisis that Berlin began to see more clearly the limitations of 'propaganda' and to move slowly but surely to embrace a cultural approach à la française.

Whether this shift would have withstood continued US apathy is impossible to say. As things developed, the policy shift was reinforced by a decisive change in US sentiment during the fall of 1923, when Germany's near economic and political collapse as well as rising criticism of French occupation policy engendered the long-awaited US intervention in the reparations question. ${ }^{51}$ The 1924 Dawes Plan provided a workable reparations schedule and paved the way for US loans, which facilitated German recovery and spelt 'the end of French predominance in Europe' (Schuker). While US involvement was the result of its economic and political interest in a stable Europe - not German actions - the experiences of the early 1920s proved more seminal to the development of German cultural diplomacy than is usually acknowledged. While little 'happened' in terms of initiatives, the post-war years forged a stronger official commitment to cultural initiative and a sharper distinction from wartime 'propaganda'. This shift was profoundly influenced by Germany's constant observation of its French rival. For Germany, France became a mirror and a place of self-diagnosis, which brought into sharp relief its own inadequacies while also offering a window onto and a blue print for a more successful future. ${ }^{52}$ To be sure, this pattern applied also to other regions of the world, but the new economic weight of the United States and its fear of political entanglements provided particularly strong incentives to act on these insights.

\section{The Transatlantic Origins of Student Exchange, 1925-30}

The end of the post-war reparations crisis in 1924 and the Locarno Accords of 1925 ushered in a more constructive phase of Weimar cultural diplomacy. A period of fairly stable government, moderate prosperity and international détente allowed Berlin to apply the lessons of the post-war years. At the same time, its foreign policy continued to be shaped by concerns for US opinion and French rivalry. Convinced that the Dawes reparations settlement would soon have to be revised, Germany continued to depend on the support of the United States and, as Ambassador Wiedfeldt concluded in November 1924, 'whether it [the United States] wants to help us and in how far it may, will depend on the attitude of the American administration and the climate of opinion in the country'. ${ }^{33}$ The US climate of opinion, however, would still develop vis-à-vis France, which held - all efforts at FrancoGerman reconciliation aside - contrary positions on reparations, occupation and disarmament. As Foreign Minister Stresemann sought to peacefully undo the Versailles order he thus sought to concile and cooperate with France just as he continued to compete with it for US favour. ${ }^{54}$ This policy he pursued not only by economic but also by cultural means.

This cultural dimension of Weimar's emerging Amerikapolitik is best illustrated by the rapid expansion of student exchanges and study abroad programmes after the mid-1920s. ${ }^{55}$ Within just a few years the German Foreign Ministry (building on private initiative, to be sure) established a student-focused academic diplomacy. In particular, it supported and increasingly oversaw organisations like the Academic Exchange Service, which began to exchange American and German students in 1924, as well as the Alexander von Humboldt Foundation, which provided fellowships to 'talented and German-friendly' international students from $1925 .^{56}$ While these two organisations were

51 Reuben Clarence Lang, 'Die Meinung in den USA über Deutschland im Jahr des Ruhrkampfes und des Hitlerputsches', Saeculum, 17 (1966), 402-16.

52 German Embassy Washington to AA, 20 July 1923, PA AA, R 80296.

53 German Embassy Washington to AA, 15 Nov. 1924, PA AA, R 80136.

54 The Locarno era gave rise to numerous private cultural initiatives to bridge the Franco-German divide, see Hans Manfred Bock, ed., Französische Kultur im Berlin der Weimarer Republik. Kultureller Austausch und diplomatische Beziehungen (Tübingen: Narr, 2005); Guido Müller, Europäische Gesellschaftsbeziehungen nach dem Ersten Weltkrieg. Das Deutsch-Französische Studienkomitee und der Europäische Kulturbund (München: Oldenbourg, 2005).

55 On German academic diplomacy and transatlantic relations in the 1920s, see Wala, 'Gegen eine Vereinzelung'.

56 Zu I D 539 4/25 (Aufzeichnung), 23 June 1925, PA AA, R 64794; Holger Impekoven, Die Alexander von Humboldt-Stiftung und das Ausländerstudium in Deutschland 1925-1945 (Bonn: V\&R Unipress, 2013), 69-77. 
outwardly represented by professorial committees to avoid charges of 'propaganda', they were heavily subsidised by the German government and by the late 1920s understood themselves as 'handmaidens of foreign policy. ${ }^{57}$ Both organisations were to identify future elites abroad, bring them in contact with their German peers and instil in them a belief in Germany's cultural grandeur as well as the legitimacy of its revisionist demands. ${ }^{58}$ At German universities, students and educators supported this policy through a host of new international clubs, houses and vacation courses. ${ }^{59}$

At this point it should be acknowledged that cooperation between official and private actors had little to do with state control or official directives. In fact, German academic organisations (even those receiving state subsidies) tended to disregard official ambitions whenever they did not align with their own. ${ }^{60}$ Rather, the state-private partnership rested on mutual objectives and priorities. Although many non-state academic diplomats were motivated by internationalist convictions, even the most liberal among them shared in the revisionist consensus of their time. In their minds, student mobility served a dual purpose: to facilitate international understanding and to convince foreign elites of the need for revision. ${ }^{61}$ It was this combination of nationalist ambition and internationalist enthusiasm (what Peter Weber has called the 'national internationalism of Weimar Germany') that forged a basis of cooperation between private and official groups, and aided the rapid development of academic diplomacy in the 1920s. By the end of the decade, the annual number of exchange students had grown from just thirteen in 1924 to 150, the number of Humboldt fellows to about sixty-five and the number of international offices at German universities from one or two to about twenty-five. In 1930 the German Foreign Ministry united all of these activities in the hands of the German Academic Exchange Service - today the world's largest academic exchange organisation.

The rapid development of this new policy field cannot be understood without accounting for the paramount role played by the United States. Initially, many of these German efforts were directed exclusively or predominantly at American students. Into the 1930s Americans constituted by far the largest group of exchange students to Germany and, despite their prosperity, also the second largest group of Humboldt fellows. ${ }^{62}$ The greatly expanding number of summer and language courses at German universities catered especially to Americans, while academic programmes like the Junior Year in Munich (founded in 1929) did so exclusively. ${ }^{63}$ While overall numbers remained modest by the standard of Cold War-era exchange programmes, in the 1920s no other country figured as prominently in Germany's international educational efforts as did the United States. This initial geographical focus on the United States was by no means 'largely coincidental', as scholars have argued. ${ }^{64}$ On the contrary, it reflected key assumptions about German soft power and French competition, as well as US culture and society.

In explaining this development it must first be noted that the pursuit of academic diplomacy was in many respects an obvious choice for Germans at the time. Next to music and the German diaspora, Wissenschaft was widely considered the most important element of German soft power. ${ }^{65}$ During the

\footnotetext{
57 See Volkhard Laitenberger, Akademischer Austausch und auswärtige Kulturpolitik, 1923-1945 (Göttingen: Musterschmidt, 1976), 314.

58 AA to v. Dirksen, 21 Mar. 1925, PA AA, R 64794.

59 Tätigkeitsbericht der Deutschen Akademischen Auslandsstelle des Verbandes der Deutschen Hochschulen (Feb. to Oct. 1929), Bundesarchiv Berlin (BArch) R8088/804.

60 Brigitte Schröder-Gudehus, Deutsche Wissenschaft und internationale Zusammenarbeit 1914-1928 (Geneva: Dumaret \& Golay, 1966), 181-211.

61 Peter Weber, 'Ernst Jäckh and the National Internationalism of Interwar Germany', Central European History, 52, 3 (2019), 402-23; Katharina Rietzler, 'Philanthropy, Peace Research, and Revisionist Politics: Rockefeller and Carnegie Support for the Study of International Relations in Weimar Germany', GHI Bulletin Supplement, 5 (2008), 61-79.

62 Düwell, Deutschlands auswärtige Kulturpolitik, 175.

63 On Heidelberg summer courses see Alexander Tutt, Ausländerbetreuung an der Universität Heidelberg, 1928-1938. Das Akademische Auslandsamt und die Vergangenheit, BA Thesis, Heidelberg University, 2012, 19.

64 Laitenberger, Akademischer Austausch, 175; Impekoven, Die Alexander von Humboldt-Stiftung, 118.

65 Friedrich Heilbron (former director of the Kulturabteilung), 'Hochschule und auswärtige Politik', in Michael Doeberl et al., eds., Das Akademische Deutschland, Vol 3 (1930), 143-52.
} 
nineteenth century German universities had attracted students from all over the world, including 10,000 Americans. ${ }^{66}$ If the belief in Germany's unique scientific and academic standing had already undergirded pre-war initiatives like the transatlantic professorial exchange, the post-war crisis made Germans all the more eager to embrace their 'scientific world reputation' ${ }^{67}$ As the famous theologian Adolf von Harnack noted in 1920, 'before the war, Germany's standing rested on its military power, its industry (and commerce) and its Wissenschaft... . Now our military power is destroyed, industry and commerce are profoundly weakened, but Wissenschaft. . . still stands. ${ }^{68}$ The founding of scientific organisations like the Emergency Association of German Science (Notgemeinschaft der deutschen Wissenschaft, today the German Research Foundation, Deutsche Forschungsgemeinschaft) in 1920 or the introduction of an academic relations desk at the German Foreign Ministry's Department of Cultural Affairs in 1926 attest to the desire to use Germany's remaining scientific prestige to recapture its international standing.

Yet Germany's focus on academic and scientific relations was clearly intensified by French competition, real and imagined. During and after the war, France systematically drew on its universities and scientific institutes to expand its cultural influence in the world. ${ }^{69}$ In the United States, French officials and educators extended visiting professorships and French language teaching, inaugurated transatlantic fellowships, supported American francophiles in establishing study abroad programmes (like the Junior Year Abroad), simplified college admissions and accreditation procedures and developed ambitious international housing projects like the Cité International Universitaire in Paris. ${ }^{70}$ The increase of American students to France, from 1,348 in 1921 to 4,000 in 1925, caused great apprehension in Germany. In German minds, French commitment to international education seemed yet another attempt to pry Americans loose from the last vestiges of German cultural influence and turn Paris, rather than Berlin, into the capital of the academic world. ${ }^{71}$

The success of French activities - especially irksome in light of Germany's perceived scientific superiority - fuelled the expansion of parallel German efforts. German professors and science organisers closely followed and often toured French innovations in the field and urged the adoption of similar measures, lest Germany fall irrevocably behind. ${ }^{72}$ The Junior Year in Paris, the Cité Internationale Universitaire and the language and civilisation courses at French universities had by the end of the decade all inspired similar German facilities. ${ }^{73}$ After the mid-1920s French inroads thus provided an important motivation as well as an organisational blueprint for German academic

66 On students in the nineteenth century, Daniela Siebe, Ausländische Studenten, auswärtige Kulturpolitik und deutsche Universitäten. 1870-1933 (Husum: Matthiesen, 2009), 109.

67 Gabriele Metzler,“"Welch ein deutscher Sieg!” Die Nobelpreise von 1919 im Spannungsfeld von Wissenschaft, Politik und Gesellschaft', Vierteljahrshefte für Zeitgeschichte 44, 2 (1996), 173-200; Sylvia Paletschek, 'Was heißt "Weltgeltung deutscher Wissenschaft"? Modernisierungsleistungen und -defizite der Universitäten im Kaiserreich', in Michael Grüttner et al., eds., Gebrochene Wissenschaftskulturen: Universität und Politik im 20. Jahrhundert (Göttingen: Vandenhoeck \& Ruprecht, 2010), 29-54.

68 Quoted from Notker Hammerstein, Die Deutsche Forschungsgemeinschaft in der Weimarer Republik und im Dritten Reich. Wissenschaftspolitik in Republik und Diktatur, 1920-1945 (Munich: Beck, 1999), 33.

69 Tomás Irish, 'From International to Interallied: Transatlantic University Relations in the Era of the First World War, 1905-1920', Journal of Transatlantic Studies, 13, 4 (2015), 311-25; Walton, 'The Junior Year Abroad', 260.

70 'Report of the Committee on Franco-American Exchange of Scholarships and Fellowships', Educational Record, 5, 3 (July 1924), 181-5; Guillaume Tronchet, 'Diplomatie universitaire ou diplomatie culturelle? La Cité internationale universitaire de Paris entre deux rives (1920-1940)', in Dzovinar Kévonian and Guillaume Tronchet, eds., La Babel étudiante. La Cité internationale universitaire de Paris (1920-1950) (Rennes: Presses Universitaires de Rennes, 2013), 59-88.

71 On the broader context, see Brigitte Schröder-Gudehus, 'Challenge to Transnational Loyalties: International Organizations after the First World War', Science Studies, 3, 2 (Apr. 1973), 93-118. On German academic apprehensions see Mitteilungen des Verbandes der Deutschen Hochschulen, 3, 4 (June 1923), 46.

72 Reinhold Schairer, Denkschrift über die Fragen der ausländischen Studenten in Deutschland, 7 Apr. 1927, BArch R8088/ 804; drawing up an agenda for cultural initiatives at Munich universities, the organisers first went on a study trip to France, see correspondence in PA AA, R 65788a.

73 Munich is a good example of each of these, having established a Junior Year in Munich, an international student house and language courses in the 1920s. See Nicole Kramer, “München ruft!” - Studentenaustausch im "Dritten Reich” am 
diplomacy. Equally important, they served as a mobilising strategy. German educators and diplomats alike realised that in light of the widespread anti-French sentiment, mentioning French advances was the single most effective way to overcome conservative opposition to allegedly 'internationalist' endeavours like student exchanges. To secure the cooperation of intransigent nationalists, German diplomats regularly and successfully played the 'French card' ${ }^{74}$ In the 1920 s the rapid ministerial, parliamentary and public commitment to costly and untested academic initiatives owed much to the legitimacy and urgency this field acquired via French competition.

And yet by themselves neither Germany's belief in its academic soft power nor French competition sufficiently explain the rapid expansion of German academic diplomacy and the specific focus on student exchange after the mid-1920s. Rather, this expansion reflected the importance of the United States to German foreign policy as well as key German assumptions about US society and the (dismal) state of US culture.

Indeed, German officials and eduactors alike believed that US universities offered a particularly fruitful place to shape US opinion. As the German professor of economics Gerhart von Schulze-Gaevernitz wrote to the Foreign Ministry after his US lecture tour in 1924, 'after all I consider the influencing of [US] universities - given the lack of any other aristocratic class - a more important field for the formation of public opinion in the long run; it is likely that from them a reversal in favor of a just reorganisation of Europe (in terms of the armistice) will emanate and assert itself ${ }^{75}$ In the atmosphere of the 1920s, efforts focusing on the allegedly 'non-political' field of culture seemed an effective way to reach Americans, who - all anxieties about 'foreign entanglements' aside - were more eager than ever to tour, study and shop in Europe. ${ }^{76}$ From this perspective, reciprocally or commercially organised academic programmes like student exchanges or vacation courses seemed to offer a particularly promising means to engage an otherwise suspicious American public.

This insight was reinforced by the widespread notion of US cultural inferiority. In spite of US economic pre-eminence, the long-standing German conviction that the United States was essentially devoid of culture, or, at best, was a culture in the making, flourished in the interwar period. ${ }^{77}$ Although Germans wisely abstained from voicing such opinions all too openly, many never came to see the United States as an academic or cultural equal. Ambassador Wiedfeldt, for example, encouraged student exchanges not because he saw any value in studying at a US university but because he saw value in studying the United States. ${ }^{78}$ For Germans, US cultural deficiencies and the country's 'youth' seemed a unique opportunity to mould the cultural affinities, and hopefully the foreign politics, of a newly important power. This partly explains the German shift of emphasis from a pre-war exchange of professors to a post-war one of students. Given the disappointments of the war (i.e. the anti-German position taken by many former US exchange professors), American students - at a more impressionable age and less burdened by wartime memories - seemed a more promising object for Germany's trust and prestige building measures. ${ }^{79}$ In short, it was in part the United States's peculiar status as a 'culturally backward' great power that prompted Germans to place special emphasis on academic diplomacy.

Last but not least, over the course of the 1920s Americans emerged as ideal partners when it came to academic exchange. Following the Great War, US internationalists began to see international education as a particularly promising means to faciliate elite reconciliation. After about 1924 organisations

Beispiel der Akademischen Auslandsstelle München’ in Elisabeth Kraus, ed., Die Universität München im Dritten Reich (München: Herbert Utz, 2006), 123-79.

74 Protocol, meeting of 6 Feb. 1925, PA AA, R 64981; German Embassy Washington to AA, 22 July 1926, PA AA, R 64981; see statement by German consul general in New York in 'Deutsche und Französische Kulturpolitik in Amerika', Hamburger Nachrichten, 7 July 1931, PA AA, R 61130.

75 Letter Schulze-Gaevernitz [1924], PA AA, R 64708.

76 Hiram Motherwell, 'The American Tourist Makes History', Harper's Magazine, 160 (Dec. 1929), 70-6.

77 See comments by the director of the German Academic Exchange Service, Adolf Morsbach, 'Die kulturellen Beziehungen zwischen den Vereinigten Staaten und Deutschland', Nationalsozialistische Monatshefte, 44 (Nov. 1933), 31.

78 German Embassy Washington to AA, 15 Sept. 1924, PA AA, R 80297.

79 Ibid. 
like the Institute of International Education (IIE, est. 1919) sought to reintegrate Germany into the academic world and to pacify its future leaders. It was in no small part the commitment and enthusiasm of men like Stephen Duggan, director of the IIE, that helped expand the student exchanges from 1923/24 onward and reinforced the German attention on the United States. ${ }^{80}$ Beyond any state interest, the dynamic development of German-American student exchanges thus rested on transatlantic internationalist networks, whose primary concerns were not international competition but international reform and cooperation. ${ }^{81}$ Apart from salient foreign policy interests, the interplay of these different factors - French competition, German cultural prejudice and cultural internationalist networks - explains why German academic diplomacy focused so heavily on the United States.

Importantly, too, these academic programmes had a much broader legacy. Although German successes never matched those of France in the 1920s, academic contacts intensified greatly, forging many a personal friendship and perhaps hastening the German-American rapprochement of the late $1920 \mathrm{~s}^{82}$ In addition, these academic programmes created an enduring network of transatlantic partners (educators, philanthropists, students), who often remained committed to GermanAmerican understanding beyond 1933, and even $1945 .{ }^{83}$ No less important, the transatlantic exchange programmes shaped the growth, direction and legitimacy of seminal organisations like the German Academic Exchange Service. In the 1920s German elites' belief in Germany's academic superiority, their fear of French competition and the special promise of a peculiar US situation came together to forge one of the most important fields of German cultural diplomacy. The reciprocal set-up of student exchange - partly decided on to appease US pride and suspicion after the Great War - has since proven highly adaptable to Germany's 'modern' cultural diplomacy, emphasising cultural exchange over cultural expansion. In this way, the 1920s United States has had a lasting impact on German cultural diplomacy well into the twenty-first century.

\section{Franco-German Competition and the European Dynamics of Cultural Diplomacy}

These developments illustrate some of the key dynamics of state-sponsored European cultural diplomacy in the 1920s. In particular, they point to patterns of mutual observation, transnational circulation and international emulation, which drove the rapid growth of cultural diplomacy in interwar Europe. While the focus has so far been on the German side of the story, French educators, tourist boosters and diplomats watched German developments with no less care and concern. Yet they arrived at very different conclusions. Whereas Germans long considered their own efforts dismal and inadequate, the French perceived a wide-ranging and in many respects superior German campaign. ${ }^{84}$ For example, while Germans regularly complained about German-Americans being politically

80 On Duggan and US internationalists, see Liping Bu, 'Education and International Cultural Understanding: The American Elite Approach, 1920-1937', in Garlitz/Jarvinen, eds., Teaching America, 111-33; see also the correspondence between Duggan and Morsbach (German Academic Exchange Service), Reel 3, Side 1 \#8 Germany, corres. with Dr. Morsbach 1929, Rockefeller Archives Center, IIE Records, Alumni and Historical Files, RG 1; for another influential internationalist and his relationship to Weimar Germany see Elisabeth Piller, 'A Tumultuous Relationship: Nicholas Murray Butler and Germany in the Era of the Two World Wars', Bulletin of the German Historical Institute, 67 (Fall 2020), 71-100.

81 See, for example, Malcolm Richardson, 'A Search for Genius in Weimar Germany: The Abraham Lincoln-Stiftung and American Philanthropy', Bulletin of the German Historical Institute, 26 (Spring 2000), 44-109; Elisabeth Piller, 'Eradicating Misunderstanding? The Institute of International Education, Student Exchanges and Transatlantic Relations in the 1920s', Rockefeller Archive Research Report, (Nov. 2018) http://rockarch.issuelab.org/resources/33683/ 33683.pdf (last accessed 31 Dec. 2020).

82 On the broader development of transatlantic academic relations and their diplomatic meaning, Wala, 'Gegen eine Vereinzelung'.

83 See Volker Berghahn, America and the Intellectual Cold Wars in Europe: Shepard Stone between Philanthropy, Academy, and Diplomacy (Princeton NJ: Princeton UP, 2001).

84 M. Petit-Dutaillis, 'L'activité de nos professeurs à l'Étranger', Information Universitaire, 23 Apr. 1932, (Clipping), PA AA, R 61187. This was often pointed out by German observers, see Fehn (Deutsche Akademie) 'Mittel und Wege Französischer Kulturpropaganda', Fränkischer Kurier, 23 Apr. 1929 (Clipping), PA AA, R 61187. 
immature and 'useless', the French saw them as a formidable power that systematically poisoned US attitudes against them. ${ }^{85}$ If anything, French apprehensions only grew stronger over the course of the 1920s. The American-German rapprochement of the late 1920s put an end to France's favoured wartime position and was, in French minds, partly due to Germany's concerted public outreach. By 1929 the 'German threat' regarding US investors, tourists and students took considerable room in French public and parliamentary debate and led to significant increases in the French public diplomacy budget. ${ }^{86}$ Special projects like plans for a Palais de France to be built in New York City or the enthusiastic French celebration of the George Washington Bicentennial in 1932 expressed this sense of competition. As the German Ambassador to Washington characterised the situation in January 1930, 'the more Germany's political and cultural position in the United States is re-won, the more intense grow third-party [French and Polish] efforts to influence American sentiment and make sure that the peace will continue to be interpreted according to the one-sided sense of the victors' ${ }^{87}$ Little wonder then, that such renewed French efforts inspired yet another round of German initiatives, including - in spite of the Great Depression - the founding of the Goethe Institut in 1932. ${ }^{88}$

Looking at both sides of this Franco-German competition offers broader insights into the dialectic development of interwar cultural politics as well as their underlying pathology. Indeed, one is struck by the often irrational nature of the two countries' mutual perceptions. Of course, French and German observations were not entirely inaccurate. Both countries did mount considerable and politically inspired cultural campaigns. Yet the very different perceptions of their success - paired with the tendency to (mis-)attribute even the most harmless cultural undertaking to official machinations - suggests that the French and German 'threat' was both real and imagined. This is also apparent from the wild claims and the emotional tone adopted in official reports and newspapers articles alike. For example, in April 1923 Das Zentrum, the organ of the Catholic Centre Party's youth organisation, noted that France 'has for decades waged a well-planned culture war against us [which it continues] without any interruption and scruples as well as with the most copious means. Its goal: Germany's destruction. ${ }^{, 89}$ A year later, the French L'homme libre found that 'German propaganda has reached a frightening degree of finesse and scientific precision. Without any scruples, it pursues world domination even after German defeat. ${ }^{, 90}$ As such hyperbole suggests, lingering paranoia continued to cloud judgments and fuel anxieties long after the war's end. But the partly irrational nature of French and German fears is suggested also by their selective nature. For example, while German observers pored over French initiatives, the innovative and effective cultural promotions of Italy or Switzerland barely registered in Berlin. Not surprisingly, it was not the extent or success of a nation's cultural diplomacy but its political implications that determined the attention it received. Accordingly, there was a strong correlation between France and Germany's political and economic fortunes and the intensity of alarm over the other country's activities. As world opinion on disarmament and reparations began to lean in German favour in the later 1920s, German diplomats and educators became notably more dismissive of French efforts, while the French became notably more concerned with German cultural diplomacy. ${ }^{91}$ In

85 German Embassy Washington to AA, 15 Nov. 1924, PA AA, R 80136. See Keylor, 'How They Advertised France', 260; on German ambitions regarding German-Americans see Michael Wala, 'Reviving Ethnic Identity: Foreign Office, Reichswehr, and German Americans during the Weimar Republic', in Wolfgang Helbich and Walter Kamphoefner, eds., German-American Immigration and Ethnicity in Comparative Perspective (Madison, WI: Max Kade Institute for German-American Studies, 2004), 326-41.

86 German Embassy Paris to AA, 11 Apr. 1930, PA AA, R 61187; 'La crise de la propaganda intellectuelle française à l'étranger', Homme Libre, 22 Sept. 1932 (Clipping), PA AA, R 61187.

87 German Embassy Washington to AA, 27 Jan. 1930, PA AA, R 80146.

88 Eckard Michels, 'Deutsch als Weltsprache? Franz Thierfelder, the Deutsche Akademie in Munich and the Promotion of the German Language Abroad, 1923-1945', German History, 22, 2 (2004), 206-28.

89 Bornemann, 'Bildungswesen, Kultur und auswärtige nationale Politik', Das Zentrum. Monatsschrift für politische Bildung, 4 (4 Apr. 1923), 57-60.

90 Quoted from 'Das Gespenst der deutschen Propaganda', Deutsche Arbeit, 24, 9 (June 1925), 244-5.

91 German Embassy Washington to AA, 30 Jan. 1925, PA AA, R 64887; Franz Thierfelder, 'Geistige Grundlagen kultureller Auslandsarbeit', Süddeutsche Monatshefte, 28, 4 (1930), 227. 
short, the French (and the German) cultural 'threat' ebbed and flowed with the state of international affairs. And while this is true for all threat perception in foreign relations, the fact that public diplomacy was built on so elusive a category as 'public sentiment' - neither stable nor (then) measurable - made it especially susceptible to interwar anxieties. It also underlines that despite France and Germany's much discussed and often sincere efforts at reconciliation, their mutual mistrust never really subsided. ${ }^{92}$

Moreover, the 'Franco-German battle for US affinities', as Robert Young has called it, offers a window into the general dynamics of cultural diplomacy in the interwar period. By demonstrating the patterns of mutual observation, transnational circulation and international emulation it helps explain why cultural diplomacy became a field of European politics in the first place and how a common repertoire of practices evolved in just a few decades' time. Indeed, Franco-German relations exemplify the dialectic development of cultural diplomacy. While German cultural diplomats and US Germanophiles copied French and Francophile initiatives (like the Junior Year Abroad or the Cite Universitaire), German actions in turn informed French efforts. ${ }^{93}$ This process of emulation was underpinned by the circulation of ideas and practices via international travel, embassy and consular missives, parliamentary debates and press articles; it was also furthered by international bodies including the League of Nations, the Carnegie Endowment and the International Confederation of Students, which published surveys on international academic initiatives and student mobility. ${ }^{94}$ But while internationalist visions motivated many interwar initiatives and helped circulate ideas and practices, it was national ambition that made cultural diplomacy a proper field of foreign policy across Europe.$^{95}$ It was ultimately the advances of political rivals that overcame official inertia and helped secure funds, commitment and legitimacy, which might not otherwise have been forthcoming in the austere interwar years. The fear of falling behind or missing out on a potential new source of international influence set in motion a process whereby - far beyond just the French or German examples - one country's innovative programme would soon be modified and adapted by another. When in 1934 the United Kingdom finally created a state-driven cultural diplomacy of its own, this step was prompted by the 'German threat' and modeled on the French example. ${ }^{96}$ Given the prevalence of national rivalries at the time, it was in this way that European governments adopted a common set of cultural diplomatic institutions and practices in the interwar years. While no European country had a state-run cultural diplomacy by 1900, nearly all of them did three decades later. Competition, in short, helps explain how and why cultural diplomacy became a widely practiced part of statecraft in the first place.

Finally, while this article sheds light on a broader mechanism - one observable, too, in other parts of the world - it also calls attention to the special role played by the United States. The rise of the new great power across the Atlantic clearly informed the emergence of European cultural diplomacies in the interwar years. The United States was a main target of European initiatives, whether they be French, German, British, Polish or Hungarian. ${ }^{97}$ Indeed, all differences aside, Europeans shared two things: a new financial dependence on the United States after the First World War and a belief in European cultural superiority. ${ }^{98}$ This combination - exacerbated by the United States's well-publicised

\footnotetext{
92 A similar point has been made about the famous meeting between Anatole de Monzie, French Minister of Education and Arts, and Prussian Minister of Culture, Carl Heinrich Becker, in 1925. See Katja Marmetschke, 'Ein Wendepunkt für die deutsch-französische Verständigung. Das Treffen zwischen dem preußischen Kultusminister C.H. Becker und dem französischen Erziehungsminister Anatole de Monzie im September 1925 in Berlin', in Bock, ed. Französische Kultur, 37-51.

93 German Embassy Paris to AA, 18 Jan. 1929, PA AA, R 246901.

94 See Institute of Intellectual Cooperation, University Exchanges in Europe: Handbook of the Institutions and Measures in all the European Countries to Facilitate the Work of Professors, Students and Teachers Abroad (Paris, 1928).

95 On the tensions between nationalism and internationalism, Daniel Laqua, 'Activism in the "Students' League of Nations": International Student Politics and the Confédération Internationale des Étudiants, 1919-1939', The English Historical Review, 132, 556 (2017), 605-37.

96 Philip Taylor, 'Cultural Diplomacy and the British Council, 1934-39', British Journal of International Studies, 4, 3 (Oct 1978), 244-65.

97 See Nagy, 'National Identities for Export'; Taylor, The Projection of Britain, 69.

98 Richard Pells, Not Like Us: How Europeans have Loved, Hated and Transformed American Culture since World War II (New York: Harper Collins, 1997), 6.
} 
aversity to foreign propaganda - led many Europeans to follow in French and German footsteps and adopt a cultural approach to win US sympathies. ${ }^{99}$ Arguably, Europe's manifest enthusiasm for transatlantic cultural exchanges in the interwar period expressed the desire to shape American opinions and the neccessity to do so by unobtrusive means. The United States's own cultural expansion, not least the well-funded initiatives of US internationalists, only reinforced this tendency. In this way, an allegedly isolationist United States profoundly shaped European (cultural) diplomacy after the First World War.

Acknowledgements. I would like to thank Tomás Irish, Benjamin Martin, Jonas Scherner, Lior Tibet and the anonymous reviewers for their helpful comments on earlier drafts of this article. I would also like to thank Ludivine Broch and Victoria Harris of Contemporary European History for all their brilliant and kind support throughout the process of publishing this article and the special issue of which it is part.

99 For example, Katharina Rietzler, 'Before the Cultural Cold Wars: American Philanthropy and Cultural Diplomacy in the Inter-War years', Historical Research, 84, 223 (Feb. 2011), 148-64.

Cite this article: Piller EM (2021). The Transatlantic Dynamics of European Cultural Diplomacy: Germany, France and the Battle for US Affections in the 1920s. Contemporary European History 30, 248-264. https://doi.org/10.1017/ S0960777321000035 